ABDIRA Volume 2 Nomor 1 Tahun 2022 Halaman 82-87

JURNAL PENGABDIAN MASYARAKAT

Research \& Learning in Faculty of Education

\title{
Belajar Bahasa Mandarin melalui Lagu
}

\author{
Dyah Tjaturrini ${ }^{1}$, Kumala Dewi Wundari ${ }^{2}$, Maherta Enggar Pramudya ${ }^{3}$ \\ Program Studi D-3 Bahasa Mandarin, Universitas Jenderal Soedirman 1,3 \\ Program Studi Bahasa dan Budaya, Universitas Bunda Mulia ${ }^{2}$ \\ e-mail: dyah.tjaturrini@unsoed.ac.id², 1859@lecturer.ubm.ac.id², \\ $\underline{\text { mahertaenggar12@gmail.com }}^{3}$
}

\begin{abstract}
Abstrak
Lagu memiliki daya tarik universal yang menghubungkan semua budaya dan bahasa. Selain berpotensi membuat pembelajaran menjadi menarik dan menyenangkan, lagu sebagai materi otentik sangat serbaguna dan dapat dikembangkan menjadi berbagai kegiatan pembelajaran. Tujuan kegiatan pengabdian ini adalah meningkatkan kemampuan berbicara dan mendengarkan bahasa Mandarin serta menguasai kosa kata dengan lebih mudah. Metode yang kami gunakan dalam kegiatan ini adalah demonstrasi dan pelatihan. Hasil dari kegiatan pengabdian ini dapat disimpulkan 2 hal; aplikasi lagu Mandarin dapat meningkatkan empat kompetensi dalam belajar bahasa asing dan dapat meningkatkan motivasi anak dalam belajar bahasa asing. Selain itu diharapkan penggunaan lagu sebagai salah satu media pembelajaran dapat memberikan referensi baru sebagai salah satu cara meningkatkan motivasi belajar anak yang digunakan dalam kegiatan belajar mengajar (KBM).
\end{abstract}

Kata Kunci: lagu, mendengarkan, berbicara, meningkatkan, kemampuan

\begin{abstract}
Song has a universal appeal that connects all cultures and languages. Besides the potential to make learning interesting and fun, songs as authentic materials are very versatile and can be developed into various learning activities. The purpose of this service activity is to improve speaking and listening skills in Mandarin and master vocabulary more easily. The methods we use in this activity are demonstrations and training. The results of this service activity can be concluded 2 things; Mandarin song applications can improve four competencies in learning foreign languages and can increase children's motivation in learning foreign languages. In addition, it is hoped that the use of songs as a learning medium can provide new references as a way to increase children's learning motivation used in teaching and learning activities (KBM).
\end{abstract}

Keyword: song, listening, speaking, improving, ability

\section{PENDAHULUAN}

Belajar bahasa dalam pikiran tiap-tiap orang adalah suatu hal yang mudah karena mereka menganggap bahwa setiap hari kita sudah menggunakan bahasa. Belajar bahasa bukanlah hanya sekedar kita bisa berkomunikasi dengan bahasa tersebut melainkan juga mengetahui dan memahami akan makna yang terkandung di dalam kata tersebut. Bahasa merupakan suara yang digunakan 
oleh setiap bangsa untuk mengungkapkan maksudnya. Jadi bahasa merupakan ungkapan suara yang dihasilkan oleh gerakan alat dan ditangkap oleh telinga. Fase-fase perkembangan bahasa dimulai dari jeritan, teriakan kemudian ocehan yang sistematis melalui peniruan dan pengajaran. Anak usia dini memperoleh kemampuan bahasa dengan sangat cepat dan hampir tanpa adanya usaha yang keras dalam kurun waktu selama tiga atau empat tahun pertama (Gleason, 1988).

Menurut Bjorklund (2005) perkembangan kemampuan berbahasa berkaitan dengan perkembangan bicara, semakin mampu orang berbicara semakin kaya kemampuan berbahasanya, semakin kaya kemampuan berbahasa membuat anak semakin percaya diri untuk berbicara. Pada masa pra sekolah kemampuan bahasa berkembang pesat, seiring dengan kebutuhan untuk bersosialisasi dan rasa ingin tahu anak. Bahkan mereka juga lebih mudah untuk belajar bahasa selain bahasa ibu, dibandingkan dengan orang dewasa. Dengan demikian mengajarkan bahasa Mandarin sebagai bahasa asing lebih tepat bila dilakukan sedini mungkin. Periode kritis/sensitif untuk belajar bahasa adalah pada anak usia dini, dimana fleksibilitas otak masih sangat baik. Perkembangan kemampuan berbahasa akan mendasari kemampuan membaca, semakin kaya penguasaan kosakata yang dimiliki maka semakin mudah anak memahami tulisan, dan pada akhirnya semakin lancar kemampuan anak membaca (Amitya:2012).

Mengingat bahasa Mandarin merupakan bahasa asing di Indonesia, tentunya proses pembelajarannya memerlukan strategi dan pendekatan yang tepat dan efektif. Keberhasilan pembelajaran bahasa Mandarin pada anak usia dini sangat dipengaruhi oleh kemampuan seorang pengajar dalam menyajikan proses kegiatan belajar mengajar yang menarik dan menyenangkan bagi anak. Pengajar harus bisa menciptakan suasana belajar dari yang biasa atau keadaan kelas yang biasa saja menjadi suatu pengalaman penemuan yang luar biasa. Untuk membangun suasana yang bagus seorang pengajar harus bisa membangun suasana kelas yang hidup dan relaks sehingga siswa bisa menerima materi dengan baik.

Selain agar dapat membangun dan menciptakan suasan kelas yang hidup relaks, pengajar juga harus dapat memotivasi pemelajar agar aktif dalam proses Kegiatan Belajar Mengajar (KBM). Hal ini disebabkan tidak adanya motivasi dalam diri siswa untuk belajar. Agar dapat menanamkan motivasi tersebut diperlukan adanya variasi dalam proses belajar. Salah satu cara yang digunakan adalah dengan menggunakan media lagu. Adanya kebiasaan mendengarkan lagu, menjadikan pelajaran bahasa Mandarin yang pada umumnya sukar untuk dipahami terkesan lebih menyenangkan dan menarik untuk dipelajari. Dalam hal ini penulis menggunakan media lagu sebagai perantara dalam pembelajaran bahasa Mandarin. Penggunaan media lagu ini dapat memotivasi dan mempermudah pemelajar dalam belajar bahasa Mandarin serta dapat merangsang otak kanan ketika sedang berkonsentrasi pada aktivitas otak kiri. 
Hal ini tentunya dapat menumbuhkan rasa ingin tahu dan dapat memotivasi pemelajar dalam belajar bahasa Mandarin. (andayu, 2009)

Penggunaan lagu merupakan salah satu strategi yang diterapkan ketika belajar bahasa asing terutama untuk anak-anak. Bagi anak-anak yang mempelajari bahasa asing apapun terutama bahasa Mandarin akan lebih semangat dan termotivasi dengan menggunakan lagu. Dari lagu mereka dapat mempelajari kosa kata dengan lebih mudah. Lagu merupakan sumber bahasa yang otentik. Hal ini didukung oleh pendapat para ahli bahasa dan pengalaman para pengajar bahasa seperti yang dinyatakan oleh Al-Faridi bahwa dengan lagu-lagu dapat membantu para pengajar untuk menciptakan pembelajaran yang aktif, kreatif dan menyenangkan (Alfaridi, 2006). Pemilihan lagu yang tepat dan sesuai dengan tema yang sedang dipelajari akan sangat membantu mempermudah anak-anak menguasai bahasa Mandarin.

Dari penjelasan di atas mendorong penulis melakukan kegiatan pengabdian di Sekolah Alam Banyu Belik Purwokerto. Pengabdian ini mengambil tema Belajar Bahasa Mandarin Melalui Lagu sebagai Tema Pengabdian Kepada Masyarakat. Diharapkan melalui penulisan ini dapat menjadi acuan pengajar bahasa Mandarin lainnya untuk meningkatkan efektivitas pembelajaran bahasa Mandarin. Selain itu juga dapat membantu anak-anak untuk dapat menguasai bahasa Mandarin dengan mudah melalui lagu.

\section{METODE}

Permasalahan yang terjadi pada setiap pemelajar bahasa asing khususnya bahasa Mandarin terutama anak-anak adalah penguasaan kosa kata. Penguasaan kosa kata dalam bahasa Mandarin tidak hanya tergantung pada bakat tetapi juga mood atau suasana hati pemelajar. Anak-anak belum mampu mengatasi suasana hati yang terkadang turun naik. Oleh karena itu harus dibangun dan diciptakan suasana kegiatan belajar mengajar (KBM) yang sangat menarik sehingga dapat meningkatkan dan memancing motivasi pemelajar.

Metode yang dianggap sesuai untuk menciptakan dan membangun suasana yang menarik bagi anak-anak adalah dengan memberikan demonstrasi dan pelatihan bahasa Mandarin menggunakan lagu. Pelatihan bahasa Mandarin dengan menggunakan lagu ini selain dapat membantu anak-anak menjaga suasana hati agar tetap senang juga diharapkan mampu meningkatkan motivasi belajar dari anak-anak itu sendiri. Suasana hati yang riang, suasana belajar yang menarik akan mampu mendorong motivasi anak-anak untuk lebih aktif dan ceria.

\section{HASIL DAN PEMBAHASAN}

\section{Belajar bahasa Mandarin}

Bahasa Mandarin merupakan bahasa umum yang dipakai masyarakat negara China. Bahasa Mandarin saat ini sudah menjadi bahasa internasional, 
sehingga beberapa negara membuka program studi yang berkaitan dengan bahasa Mandarin. Dalam praktiknya, bahasa Mandarin tidak hanya diajarkan kepada anak-anak sampai mahasiswa saja, namun kepada seluruh elemen masyarakat. Bahasa Mandarin sudah diajarkan sedari dini, mulai dengan belajar mendengar, berbicara, menulis dan mendengarkan.

Dalam proses pembelajarannya, bahasa Mandarin merupakan bahasa yang fleksibel dan mudah dipahami apabila terus dipelajari. Belajar bahasa Mandarin dapat dimulai dengan rajin membaca buku, menghafalkan kosa kata sampai dengan mendengarkan lagu-lagu Mandarin.

\section{Belajar Melalui Lagu}

Metode pembelajaran paling umum yang seru namun tetap menambah ilmu adalah dengan menggunakan lagu. Penggunaan lagu dalam kegiatan pembelajaran bahasa Mandarin sebenarnya bukan sebuah hal baru. Terdapat banyak lagu berbahasa Mandarin mulai dari lagu dengan tempo cepat yang terkadang susah diikuti hingga lagu dengan tempo lambat yang dapat diikuti dengan mudah. Pengajar dapat memilih lagu mana yang sesuai untuk pembelajaran maupun tidak.

Lagu digunakan sebagai teknik/media dalam proses pembelajaran bahasa Mandarin Hal ini dikarenakan hampir tidak ada batas waktu dalam menggunakan media lagu untuk mengajar bahasa Mandarin. Maksudnya adalah pemelajar dalam hal ini anak-anak dapat menggunakan lagu sebagai input bahasa sesuka hati mereka, kapan pun mereka mau, baik di dalam kelas maupun di luar kelas. Mereka bisa menyanyikan lagu tersebut dimana saja, dan kapan saja mereka kehendaki. Secara alamiah mereka bersentuhan secara cepat dengan bahasa Mandarin dan menikmati proses ini.

\section{Bentuk Penerapan Pembelajaran Bahasa Mandarin melalui Lagu}

Untuk meningkatkan kemampuan listening menggunakan lagu sebagai metode pembelajaran maka pengajar harus mempersiapkan lagu-lagu berbahasa Mandarin dengan beberapa tempo yang berbeda. Dimulai dari tempo yang lambat sampai dengan tempo yang cepat. Hal ini memudahkan siswa untuk mendengar kata-kata dalam lagu tersebut dengan lebih jelas. Hal ini juga bertujuan untuk meningkatkan level kesulitan listening dengan lagu secara bertahap. Setelah pengajar memperdengarkan lagu kepada pemelajar, , pengajar lalu dapat memberikan pertanyaan-pertanyaan sesuai dengan isi lagu tersebut. Apabila pemelajar dapat menjawab pertanyaan tersebut dengan benar maka membuktikan bahwa pemelajar mampu mendengar dan memahami isi lagu tersebut. Cara lain yang dapat digunakan adalah pengajar memutarkan lagu tersebut kemudian pemelajar menuliskan lirik lagu tersebut. Khusus untuk anakanak setelah mendengarkan lagu tersebut dapat bermain tebak-tebakan seputar lagu tersebut.

Cara lain dalam memanfaatkan lagu untuk meningkatkan kemampuan bahasa Mandarin adalah dengan cara pemelajar menyanyikan lagu tersebut 
dengan melihat pada teks yang dia tulis dan kemudian pemelajar yang menyanyikan lagu tersebut memberikan pertanyaan kepada pemelajar lainnya mengenai isi lagu tersebut. Hal ini pun dapat meningkatkan kemampuan pemelajar dalam membaca/reading. Untuk membuat suasana yang lebih menarik, pengajar juga dapat menunjuk siswa yang lainnya menjadi pembawa acara dan juga juri layaknya sebuah kontes menyanyi.

\section{Dampak dari Pembelajaran Bahasa Mandarin melalui Lagu}

Dalam metode pembelajaran menggunakan lagu ini, hal yang perlu ditekankan kepada anak-anak adalah penilaian yang dilakukan bukan merupakan penilaian menyanyi namun pelafalan kata dalam lagu tersebut. Ditekankan pada anak-anak untuk berani berekspresi dengan lagu yang diberikan meskipun tidak memiliki suara indah atau suaranya tidak sesuai dengan irama lagu. Metode pembelajaran dengan menggunakan lagu tidak hanya dapat digunakan untuk melatih kemampuan listening, reading, writing saja tetapi juga kemampuan speaking.

Lagu merupakan sarana untuk menarik minat pemelajar dalam belajar bahasa Mandarin khususnya anak-anak. Anak-anak dapat belajar kosa kata baru melalui lagu tersebut. Tidak hanya mengetahui arti dari kata yang ada di lagu tersebut. Akan tetapi, anak-anak juga dapat memahami makna sebenarnya dari lagu yang mereka dengarkan. Melalui tanya jawab yang dilakukan setelah mendengarkan lagu tersebut maka mereka juga diminta untuk berani mengucapkan jawabannya sesuai dengan pertanyaan yang diberikan.

Hasil dari pengabdian ini tidak jauh berbeda dengan kegiatan pengabdian atau penelitian lainnya yang menggunakan lagu sebagai salah satu media pembelajaran. Seperti dalam salah satu kutipan di bawah ini

Hakekat lagu itu berarti sekumpulan kata-kata yang dinyanyikan dan diiringi dengan menggunakan alat musik tertentu. Senada dengan hal tersebut seorang ahli mengemukakan pendapatnya tentang lagu sebagai karya musikal pendek, dengan teks yang puitis, yang sama-sama pentingnya antara musik dan kata- kata. Karya itu bisa tertulis, beberapa dalam bentuk suara dan biasanya dibarengi dengan instrumen (Encyclopedia dalam Ifadah dan Aimah, 2012: 365).

lagu merupakan bagian yang penting dari pembelajaran bahasa Inggris karena lagu menjadikan para siswa lebih sensitif terhadap bunyi, dan mempelajari bahasa Inggris tidak lain adalah mempelajari berbagai jenis bunyi yang bermakna. Lagu juga bisa menjadikan kelas lebih menarik dan semarak. Saat anak menyukai lagu yang diajarkan guru, mereka akan dengan senang hati dan antusias melakukannya. Dan saat itulah, secara tidak langsung mereka tengah mempelajari sesuatu (Ranuntu \& Tulung, 2018)

Dari kutipan diatas, dapat disimpulkan bahwa ada beberapa alasan mengapa lagu digunakan sebagai salah satu media pembelajaran dan dianggap cukup efektif untuk mengajar bahasa Mandarin bagi pemelajar sekolah dasar. Selain itu, sasaran pengajaran Bahasa Mandarin adalah anak-anak Sekolah Alam 
Banyu Belik Purwokerto dan bahasa Mandarin merupakan bahasa asing, sehingga pemilihan media lagu bahasa Mandarin yang sesuai dapat menciptakan suasana belajar yang menyenangkan (joyful learning)., menarik dan dapat juga meningkatkan motivasi belajar anak-anak.

\section{SIMPULAN}

Dari pembahasan di atas, dapat disimpulkan bahwa metode pembelajaran dengan menggunakan lagu dapat membantu pemelajar dalam menguasai bahasa asing yaitu bahasa Mandarin. Dengan lagu pemelajar dapat meningkatkan beberapa kompetensi yang harus dikuasai ketika belajar bahasa asing. Dengan lagu pemelajar dapat meningkatkan kompetensi mendengar (listening), berbicara (speaking) ketika melakukan tanya jawab dalam bentuk game, dan membaca (reading) serta menulis (writing) meski untuk kompetensi menulis ini lebih kecil prosentasenya. Hal ini sesuai dengan yang disampaikan oleh Alwasiah (2010) mempelajari bahasa berarti harus menguasai empat aspek penting dalam pembelajaran bahasa yaitu reading, listening, speaking dan writing.

\section{DAFTAR PUSTAKA}

Amy Kadarharutami, M. Psi. (2011). Sukses Mengasuh Anak Usia 3-6 Tahun.

Direktorat Pembinaan Pendidikan Anak Usia Dini Nonformal dan Informal Kememterian Pendidikan dan Kebudayaan.

Anandayu, Ayu. (2009). Peningkatan Motivasi Siswa Dalam Belajar Bahasa Mandarin Dengan Media Lagu Di SMA 2 Wonogiri. Program Diploma III Bahasa Mandarin. Fakultas Sastra dan Seni Rupa Universitas Sebelas Maret, Surakarta

Alwasiyah, Chaedar. (2010). Filsafat Bahasa dan Pendidikan (ed.2).Bandung Remaja Rosdakarya

Brewster, J., Ellis, G., Girard, D. (2002). The Primary English Teachr's Guide. England: Penguin English.

Cameron, L. (2001). Teaching Languages to Young Lerner. Cambridge: CUP.

Ellis, R. (1994). Second Language Acquisition. Oxford: OUP

Purwanti, Dewi. (2011). Penggunaan Lagu-lagu Mandarin Sebagai Media Pembelajaran Bahasa Mandarin Kelas 3 di SD Tripusaka, Surakarta .Program Diploma III Bahasa Mandarin. Fakultas Sastra dan Seni Rupa Universitas Sebelas Maret, Surakarta

Ranuntu, Garryn. C., Tulung, Golda, J. (2018). Peran Lagu Dalam Pengajaran Bahasa Inggris Tingkat Dasar. Jurnal LPPM Bidang EkoSusBudKum, 4 (1), 106107

http://www.eslgames.com/edutainment/songs.htm

https://jatengpos.co.id/belajar-bahasa-inggris-seru-dengan-lagu/ 